\title{
Nutrient-stimulated glucagon-like peptide 1 release after body-weight loss and weight maintenance in human subjects
}

\author{
Tanja C. M. Adam*, Manuela P. G. M. Lejeune and Margriet S. Westerterp-Plantenga \\ Nutrition and Toxicology Research Institute Maastricht (NUTRIM), Department of Human Biology, Maastricht University PO Box \\ 616, 6200 MD Maastricht, The Netherlands
}

(Received 27 January 2005 - Revised 4 August 2005 - Accepted 5 September 2005)

\begin{abstract}
Glucagon-like peptide 1 (GLP-1) is a peptide hormone that is released in response to nutrient ingestion. Postprandial GLP-1 release has been reported to be attenuated in obese subjects, but reports on the effect of weight loss on GLP-1 are conflicting. The aim of the present study was to clarify the effect of a weight-loss period and a consecutive weight-maintenance period on nutrient-stimulated GLP-1 release in obese subjects. Nutrient-stimulated (standard breakfast; 1.9 MJ) GLP-1 release was investigated in thirty-two obese subjects on three occasions: before weight loss (T1) (BMI 30.0 (SD 2.5) kg/m²); after a 6-week very-low-energy diet (VLED) (T2) (BMI 27.6 (SD 2.3) $\mathrm{kg} / \mathrm{m}^{2}$ ); after a 3-month weight-maintenance period (T3) (BMI 27.9 (SD 2.3) $\mathrm{kg} / \mathrm{m}^{2}$ ). At each occasion, following a fasting blood sample the test meal was fed and blood was drawn every $30 \mathrm{~min}$ for $2 \mathrm{~h}$ relative to ingestion in order to determine plasma GLP-1, insulin, glucose and NEFA concentrations. Subjects lost 7 (SD 3.4) $\mathrm{kg}$ during the VLED $(P<0.0001)$ and regained 1 (SD 3.2) $\mathrm{kg}$ during the weight-maintenance period (NS). The area under the curve for nutrient-stimulated plasma GLP-1 $(\mathrm{pmol} / 1 \times \mathrm{h})$ was significantly decreased $(P=0.01)$ at T2 (6.8 (SD 1)) compared with T1 (12.8 (SD 2.9)) and T3 (11.1 (SD 1.5)). Since we found a rebound of concentrations after a weight-maintenance period, decrease after weight loss seems to be transient and possibly due to a negative energy balance.
\end{abstract}

Obesity: Glucagon-like peptide 1: Weight loss: Weight maintenance: Appetite: Very-low-energy diets

Along with the attempt to find a 'cure' for the obesity epidemic, increasing attention has been given to the role of gut hormones in the development of obesity as well as in weight loss and weight maintenance. Weight loss is associated with a marked health improvement and a decreased risk of CVD and type 2 diabetes mellitus (van Gaal et al. 1997; Murphy \& Bloom, 2004). For long-term effects of weight loss, the weight-maintenance period after actual weight loss seems to be more crucial. Factors such as an increase in cognitive restraint have been shown to work beneficially for weight maintenance (Clark et al. 1994; Lejeune et al. 2003b). Factors suggested as being related to the development of obesity are decreased physical activity and/or increased energy intake. Weight loss can thus be achieved by reducing energy intake and/ or increasing energy expenditure.

Energy intake is partly controlled by neural and humoral signals that are generated by a biological system that senses and processes food and that has impact on the satiating efficiency of food (Blundell et al. 1993). One of the supposed mediators that is involved in the development of post-meal satiety and possibly contributes to satiation is glucagon-like peptide 1 (GLP-1) (Blundell \& Näslund, 1999).
GLP-1 is a thirty amino acid peptide hormone that is released from intestinal $\mathrm{L}$ cells into the circulation after a mixed meal (Holst, 1994; Näslund et al. 1999a). Peripheral GLP-1 administration compared with saline infusions reduced food intake and suppressed appetite in normal weight-subjects (Flint et al. 1998) and led to lower hunger ratings and decreased energy intake during an ad libitum meal in obese subjects (Näslund et al. 1999a). The role of GLP-1 and its possible contribution to obesity is not clear yet. One study has reported hypersecretion of GLP-1 in obese subjects (Fukase et al. 1993). However, there also is evidence that postprandial GLP-1 release in response to carbohydrate and mixed-meal ingestion seems to be attenuated in obese subjects (Ranganath et al. 1996; Verdich et al. 2001b). Outcomes of studies examining the effect of weight loss on GLP-1 concentrations in obese subjects are ambivalent. While increased concentrations have been found after weight loss (Näslund et al. 1999a; Verdich et al. 2001a), others report decreased concentrations of appetite-related peptides after weight loss (Cigaina \& Hirschberg, 2003). The aim of the present study was to clarify the effect of diet-induced weight loss on GLP-1 concentrations in obese subjects and in particular the development of GLP-1 concentrations during consecutive weight maintenance following weight loss.

Abbreviations: DPP, dipeptidyl-peptidase; E \%, energy percent; FFM, fat-free mass; GLP-1, glucagon-like peptide 1; REE, resting energy expenditure; VLED, very-low-energy diet.

Corresponding author: Dr T. C. M. Adam, fax +31 43367 0976, email T.Adam@hb.unimaas.nl 


\section{Methods}

\section{Subjects}

Forty subjects were recruited by advertisements in local newspapers or flyers at the Maastricht University that included the inclusionary criteria for the present study. Eight subjects did not complete the study and only data for the thirty-two completers are presented.

Thirty-two overweight or obese class 1 (BMI $30 \cdot 1$ (SD 2.6) $\mathrm{kg} / \mathrm{m}^{2}$ ) subjects (average age 44 (SD 9) years; twenty-three women, mean age 43 (SD 8) years, range 20-59 years; nine men, mean age 46 (SD 12) years, range $28-60$ years), according to the classification of the WHO (BMI $\geq 25$ and $<34.9 \mathrm{~kg} / \mathrm{m}^{2}$ ) (World Health Organization, 1998), participated in the study. Selection criteria included being in good health, not taking any medications, and no history of diabetes or chronic disease.

Informed written consent was obtained and the study was approved by the medical ethics committee of the Maastricht University.

\section{Experimental design}

A repeated measurement design was applied to the thirty-two selected subjects including three visits: before weight loss (T1); after a 6-week weight-loss period (T2) with a verylow-energy diet (VLED); after a 12-week weight-maintenance period (T3). Each time, subjects came to the laboratory in the morning in a fasted state. They were instructed to fast from 22.00 hours the night before the test day. After the questionnaires were completed, urine samples were collected, resting energy expenditure (REE) was measured and an indwelling cannula (Baxter BV, Utrecht, The Netherlands) was inserted in an antecubital vein. After 20 min of rest, subjects received a standard breakfast. The breakfast (1.9 MJ) had an energy density of $3.9 \mathrm{~kJ} / \mathrm{g}$ and consisted of two slices of brown bread $(100 \mathrm{~g})$, baked egg $(85 \mathrm{~g})$ and $300 \mathrm{ml}$ skimmed milk. The distribution of energy was 48.8 energy percent (E \%) carbohydrates, $28.5 \mathrm{E} \%$ protein and $22.6 \mathrm{E} \%$ fat.
Blood samples were taken for a total of $2 \mathrm{~h}$, every $0.5 \mathrm{~h}$ relative to ingestion of the breakfast for determining plasma GLP-1, insulin, glucose and NEFA concentrations.

To determine the appetite profile, subjects rated their subjective feeling of hunger and satiety (how satiated do you feel) on anchored $100 \mathrm{~mm}$ visual analogue scales with the left anchor 'not at all' and the right anchor 'extremely' 15 min before the meal (time point 0 ), immediately after the meal (time point 30), and during the rest of the test day every $30 \mathrm{~min}$ relative to the measurement after the meal for a total of $120 \mathrm{~min}$.

After the baseline measurements at the first appointment, a VLED intervention followed for 6 weeks to promote weight loss. The VLED (Optifast ${ }^{\circledR}$; Novartis Consumer Health, Osthofen, Germany) was supplied in three sachets per d, dissolved in water to obtain a milk shake, pudding or soup. Three sachets provided $2540 \mathrm{~kJ} / \mathrm{d}$, consisting of $52.5 \mathrm{~g}$ protein $(35 \mathrm{E}$ $\%), 13.5 \mathrm{~g}$ fat $(20 \mathrm{E} \%)$ and $67.5 \mathrm{~g}$ carbohydrate (45 E \%). A maximum of $200 \mathrm{~g}$ vegetable or fruit were allowed in addition to the VLED.

After the 6 weeks of the VLED all measurements were repeated. The last appointment followed after a 12-week weight-maintenance period. During the weight-maintenance period subjects had no specific instructions about diet or physical activity.

\section{Anthropometry}

All anthropometrical data were obtained three times, before and after weight loss and after weight maintenance (Table 1).

For all subjects, body weight was measured on a digital balance (Seca, Hamburg, Germany), with subjects in underwear, in a fasted state, and after voiding their bladder. Height was measured using a wall-mounted stadiometer (Seca, Hamburg, Germany). The BMI was calculated as body weight/height ${ }^{2}$ $\left(\mathrm{kg} / \mathrm{m}^{2}\right)$.

The distribution of fat was determined by measuring the waist and hip circumferences and calculation of the waist:hip ratio. The waist circumference was measured at the site of the smallest circumference between the rib cage and the ileac

Table 1. Subject characteristics ( $n$ 32; twenty-three women and nine men)

(Mean values and standard deviations)

\begin{tabular}{|c|c|c|c|c|c|c|c|}
\hline & \multicolumn{2}{|c|}{$\begin{array}{l}\text { Before weight } \\
\text { loss (T1) }\end{array}$} & \multicolumn{2}{|c|}{$\begin{array}{l}\text { After weight loss } \\
\text { (T2) }\end{array}$} & \multicolumn{2}{|c|}{$\begin{array}{c}\text { After weight } \\
\text { maintenance (T3) }\end{array}$} & \multirow[b]{2}{*}{$P+$} \\
\hline & Mean & SD & Mean & SD & Mean & SD & \\
\hline Body weight (kg) & $86 \cdot 7$ & $8 \cdot 8$ & $79 \cdot 7^{\star}$ & $8 \cdot 4$ & $80 \cdot 7^{\star}$ & $9 \cdot 6$ & 0.0001 \\
\hline BMI $\left(\mathrm{kg} / \mathrm{m}^{2}\right)$ & $30 \cdot 0$ & 2.5 & $27 \cdot 6^{\star}$ & $2 \cdot 3$ & $27 \cdot 9^{\star}$ & $2 \cdot 3$ & 0.0001 \\
\hline Body fat $(\%)$ & $38 \cdot 1$ & $6 \cdot 1$ & $33 \cdot 8^{*}$ & $7 \cdot 7$ & $33 \cdot 6^{\star}$ & $7 \cdot 6$ & 0.0001 \\
\hline Fat-free mass $(\mathrm{kg})$ & $54 \cdot 3$ & 7.9 & $53 \cdot 4$ & $7 \cdot 7$ & 53.9 & $8 \cdot 8$ & NS \\
\hline $\mathrm{RQ}$ & 0.83 & 0.04 & $0.78^{\star}$ & 0.05 & $0 \cdot 86^{*}$ & 0.06 & 0.0001 \\
\hline Fat oxidation $(\mathrm{g} / \mathrm{h})$ & 4.0 & $1 \cdot 3$ & $5 \cdot 4^{*}$ & 1.8 & $3 \cdot 3^{*}$ & $2 \cdot 0$ & 0.0001 \\
\hline Resting energy expenditure (MJ/d) & $7 \cdot 3$ & 0.9 & $7 \cdot 1$ & $1 \cdot 0$ & $6 \cdot 9$ & 0.88 & NS \\
\hline Factor 1 (cognitive restraint) $\ddagger$ & $6 \cdot 5$ & $4 \cdot 3$ & $11 \cdot 2^{*}$ & $4 \cdot 4$ & $10 \cdot 5^{\star}$ & $4 \cdot 3$ & 0.0001 \\
\hline Factor 2 (disinhibition) $\ddagger$ & $6 \cdot 1$ & $3 \cdot 1$ & $4 \cdot 9^{\star}$ & 2.5 & $4 \cdot 8^{*}$ & 2.9 & 0.005 \\
\hline Factor 3 (hunger) $\ddagger$ & $5 \cdot 3$ & 3.9 & $3 \cdot 6^{*}$ & $2 \cdot 7$ & $3 \cdot 1^{*}$ & $2 \cdot 7$ & 0.0004 \\
\hline
\end{tabular}

${ }^{*}$ Mean value was significantly different from that before weight loss $(P<0.05)$.

† Statistical significance was determined by ANOVA for repeated measures.

$\ddagger$ Dietary restraint, disinhibition and hunger measured with factor 1,2 or factor 3 respectively of the three-factor eating questionnaire.

For details of subjects and procedures, see p. 161. 
crest, with the subjects in standing position. The hip circumference was measured at the site of the largest circumference between the waist and the thighs. The waist:hip ratio was calculated by dividing the waist circumference by the hip circumference.

Body composition was measured by using the ${ }^{2} \mathrm{H}_{2} \mathrm{O}$ dilution technique (Schoeller et al. 1980). The dilution of the ${ }^{2} \mathrm{H}_{2} \mathrm{O}$ isotope is a measure for total body water (van Marken Lichtenbelt et al. 1994). The evening before the three test days, subjects drank a ${ }^{2} \mathrm{H}_{2} \mathrm{O}$ dilution $(70 \mathrm{~g}$ water with an enrichment of 5 atom\% excess ${ }^{2} \mathrm{H}$ ) after voiding. ${ }^{2} \mathrm{H}_{2} \mathrm{O}$ enrichment was measured in urine from the second voiding of the following morning. ${ }^{2} \mathrm{H}$ concentrations in the urine samples were measured using an isotope ratio MS (Micromass Optima, Manchester, UK). Total body water was determined by dividing the measured ${ }^{2} \mathrm{H}$ dilution space by 1.04 (Schoeller et al. 1980).

Fat-free mass (FFM) was calculated by dividing the total body water by the hydration factor 0.73 . By subtracting FFM from body weight, fat mass was obtained. Percentage of body fat was calculated according to the equation of Siri (1956).

\section{Resting energy expenditure and substrate oxidation}

REE was measured by means of an open-circuit ventilated hood system. Subjects came to the laboratory in the morning by car or by bus to minimise the amount of physical activity before the test. REE was measured at the beginning of each of the test days with subjects in a fasted state while lying supine for $30 \mathrm{~min}$. Gas analyses were performed by a paramagnetic $\mathrm{O}_{2}$ analyser (Servomex type 500A; Servomex Dontrols Ltd, Crowborough, Sussex, UK) and an IR $\mathrm{CO}_{2}$ analyser (Servomex type 500A), similar to the analysis system described by Schoffelen et al. (1997). Calculation of REE was based upon Weir's formula (Weir, 1949). RQ was calculated as $\mathrm{CO}_{2}$ produced $/ \mathrm{O}_{2}$ consumed.

Fat oxidation was calculated using the following equation (Peronnet \& Massicotte, 1991):

Fat oxidation $(\mathrm{g} / \mathrm{h})=1.695 \times \mathrm{V}_{\mathrm{O}_{2}}($ litres $/ \mathrm{min})-1.701 \times$ $\mathrm{V}_{\mathrm{CO}_{2}}$ (litres/min) $\times 60$.

\section{Ambient temperature}

Data on $24 \mathrm{~h}$ average ambient temperature were supplied by the Royal Dutch Meteorological Institute and were collected at a location near the university (Maastricht, Beek; $51^{\circ}$ North, $6^{\circ}$ East).

\section{Attitude towards eating}

Eating behaviour was analysed at the beginning of each test day using a validated Dutch translation of the three-factor eating questionnaire (Stunkard \& Messick, 1985; Westerterp-Plantenga et al. 1999). Cognitive restrained and unrestrained eating behaviour (factor 1, twenty-one items), emotional eating and disinhibition (factor 2, sixteen items) and the subjective feeling of hunger (factor 3, fourteen items) were scored.

\section{Blood parameters}

Blood samples for GLP-1 were taken in iced syringes and mixed with EDTA and $40 \mu$ l dipeptidyl-peptidase IV inhibitor (DPP-IV inhibitor; Linco Research, St Charles, MO, USA) that prevents degradation of hormones such as GLP-1 by the DPP-IV enzyme. Blood samples for other blood parameters were mixed with EDTA to prevent clotting. Plasma was obtained by centrifugation for $10 \mathrm{~min}$ at $2800 \mathrm{~g}$ at $4^{\circ} \mathrm{C}$. Plasma was collected, frozen in liquid $\mathrm{N}_{2}$ and stored at $-20^{\circ} \mathrm{C}$ for analysis.

GLP-1 concentrations were measured using an ELISA (EGLP-35K; Linco Research Inc.) for non-radioactive quantification of biologically active forms of glucagon-like peptide. The assay has an intra-assay CV of $8 \%$ or less and an interassay CV of $12 \%$ or less. Sensitivity of the analysis is $2 \mathrm{pmol} / \mathrm{l}$ (Nathan et al. 1992).

Plasma glucose concentrations were determined using the hexokinase method (Glucose HK $125 \mathrm{kit}$; ABX diagnostics, Montpellier, France). The WAKO NEFA C-kit (Wako Chemicals, Neuss, Germany) was used to determine NEFA concentrations.

Insulin concentrations were measured using a RIA kit (Insulin RIA-100; Pharmacia, Uppsala, Sweden).

\section{Statistical procedures}

Data are presented as means with their standard errors or as means and standard deviations. Sex differences were assessed using factorial ANOVA and corrected for baseline differences. All figures show changes from fasting plasma concentrations at each time of blood sampling $(\Delta)$ at the three testing occasions T1, T2 and T3 or area under the curve. Differences for blood parameters, appetite profile and anthropometrical data between T1, T2 and T3 were determined by ANOVA for repeated measures and Sheffé F post hoc test (Statview SE Graphics ${ }^{\mathrm{TM}}$, Abacus Concepts Inc, Berkeley, CA, USA). Area under the curve was calculated as incremental area under the curve over time $(2 \mathrm{~h})$, using the trapezoidal method. Pearson correlation coefficients, $r$, were calculated to determine the relationship between REE and FFM.

A possible relationship between changes in the different appetite ratings and in GLP-1 concentrations after a meal were assessed by regression analysis. Whether the decrease in GLP-1 release after weight loss compared with before weight loss was related to $\Delta$ body fat, $\Delta$ body weight and age was tested with the same method. All analyses were performed with Statview SE Graphics ${ }^{\mathrm{TM}}$. The level of significance was set at $P<0.05$.

\section{Results}

\section{Anthropometrical results}

Anthropometrical data are shown in Table 1.

All anthropometrical results were compared between men and women using factorial ANOVA. There was no sex effect, except for weight loss. Women lost 5.8 (SD 2.7) kg, while men lost 9.8 (SD 2.8) $\mathrm{kg}(P<0.001)$. Thus, all further data have been taken together for men and women.

During the 6-week VLED, subjects had lost 8 (range $1-14.8) \%$ of their weight. This was followed by a 
non-statistically significant $1.2 \%$ regain during the 12 -week weight-maintenance period. With regard to body composition, reduction of percentage fat mass was significant after weight loss ( $F_{1,31} 61 \cdot 8 ; P<0.0001$; compared with baseline) as well as after weight maintenance $\left(F_{1,31} 60 \cdot 7 ; P<0 \cdot 0001\right)$. FFM decreased slightly, but not statistically significant over time. At T2 as well as at T3 factor 1 of the three-factor eating questionnaire (restraint scores) was significantly increased $\left(F_{1,31}\right.$ 56.4; $P<0.0001$; and $F_{1,31} 52.3 ; P<0.0001$, respectively) compared with $\mathrm{T} 1$. In addition, factor two (disinhibition) and three (hunger) were significantly reduced $\left(F_{1,31} 8 \cdot 3\right.$; $P<0.05$ and $F_{1,31} 7.7 ; P<0.05$ respectively) compared with baseline.

RQ was significantly reduced at T2 compared with T1 $\left(F_{1,31} 52.9 ; P<0.0001\right)$, indicating increased fat oxidation, and significantly increased at T3 compared with $\mathrm{T} 2\left(F_{1,31}\right.$ 54.8; $P<0.0001)$, indicating normal substrate oxidation again. At all time points REE was significantly related to FFM before weight loss (T1, $r 0.81 ; P<0.0001$ ), after weight loss $(\mathrm{T} 2, r 0.43 ; P<0.05)$ and after weight maintenance (T3, $r$ 0.65; $P<0.05$ ) (Fig. 1).

\section{Blood parameters}

After weight loss, mean plasma GLP-1 (pmol/l) concentration in the fasting blood sample tended to be lower compared with before weight loss (2.6 (SEM 0.61) v. 4.7 (SEM 1.3)), ( $F_{1,31}$ $60.7 ; P=0.06)$. Decrease in baseline GLP-1 concentrations after weight loss were unrelated to decreases in body weight or body fat. Fasting GLP-1 concentrations at T3 (4.1 (SEM $0 \cdot 9)$ ) were comparable with fasting concentrations at T1 (4.7 (SEM 1.3)).

Plasma GLP-1 concentrations expressed as change from the fasting blood sample $(\Delta)$ were significantly increased after ingestion of the breakfast before weight loss (T1) and after weight maintenance (T3). Post hoc testing revealed a significant increase at 30,60, 90 and $120 \mathrm{~min}$ at both occasions (T1, $F_{1,31} 8.2 ; \quad P<0.05, \quad F_{1,31} \quad 8.0 ; \quad P<0.05, \quad F_{1,31} \quad 7.8$; $P<0.05, F_{1,31} 7.9 ; P<0.05$ and $\mathrm{T} 2, F_{1,31} 8.3 ; P<0.05, F_{1,31}$ $\left.7.7 ; P<0.05, F_{1,31} 7.8 ; P<0.05, F_{1,31} 7.9 ; P<0.05\right)$. After weight loss (T2), plasma GLP-1 concentrations after breakfast

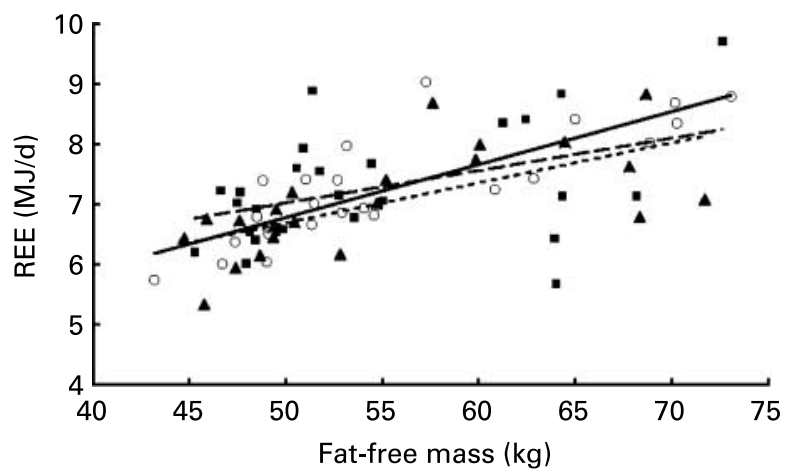

Fig. 1. Resting energy expenditure (REE) as a function of fat-free mass ( $n$ 32; twenty-three females and nine males) before weight loss $(\mathrm{O}, \ldots$, $y=0.09 x+2.38 ; P=0.0001)$, after weight loss $(\mathbf{\square},---, y=0.05 x+4.33$; $P=0.02)$ and after weight maintenance $(\boldsymbol{\Lambda}, \quad \cdots, \quad y=0.07 x+3.37$; $P=0.001$ ). For details of subjects and procedures, see p. 161 . were not significantly different from fasting plasma concentrations.

The changes in plasma GLP-1 concentrations were significantly lower after weight loss compared with before weight loss at $60 \mathrm{~min}$ after breakfast $(0.83$ (SEM 0.48) v. 2.5 (SEM 0.52)) $\left(F_{1,31} 24.9 ; P<0 \cdot 001\right)$.

The area under the curve for plasma GLP-1 concentrations before weight loss (12.8 (SEM 2.9)) and after weight maintenance (11.1 (SEM 1.5)) were significantly higher compared with after weight loss (6.8 (SEM 1.0)) $\left(F_{2,30} 15 \cdot 7 ; P<0 \cdot 01\right.$ compared with $\mathrm{T} 1$ and $F_{2,30} 14.2 ; P<0.01$ compared with T3) (Fig. 2).

Fasting insulin concentrations at T1 (11.5 (SEM 1.08)), T2 (11.5 (SEM 0.8)) and T3 (11.6 (SEM 1.2)) were not different.
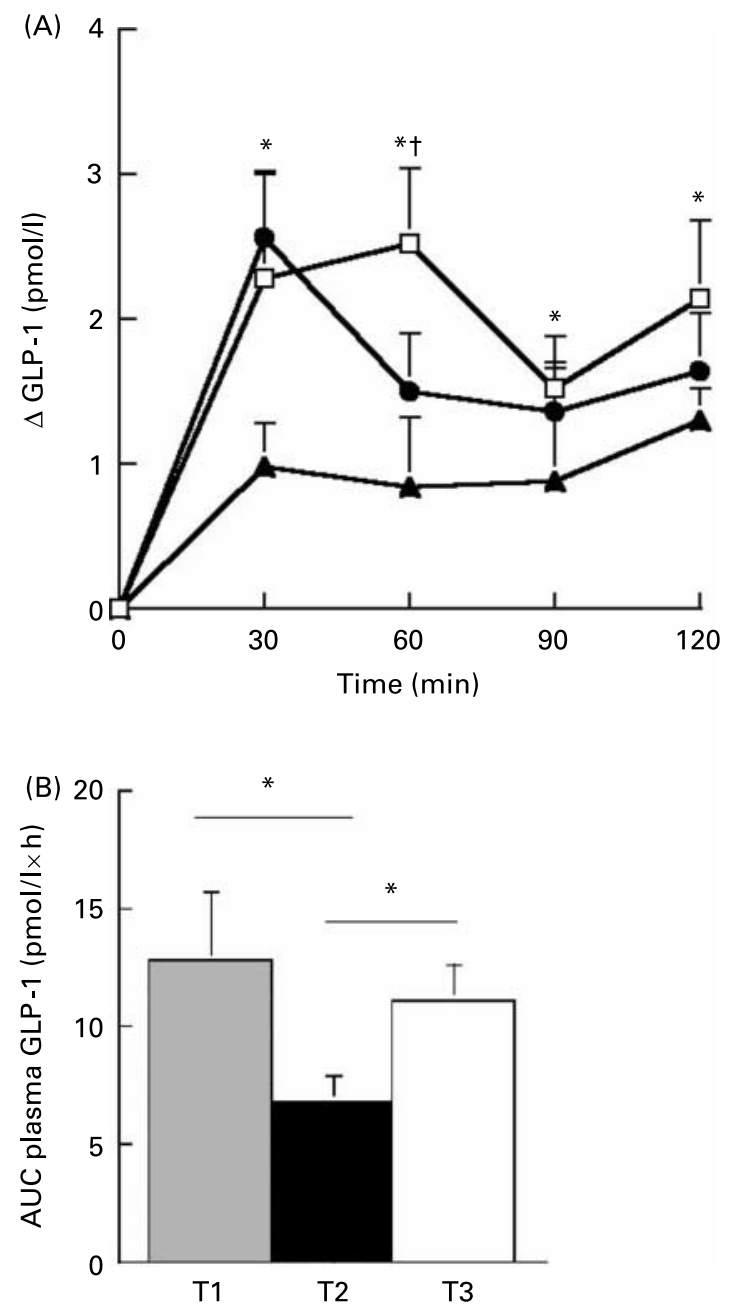

Fig. 2. Plasma glucagon-like peptide 1 (GLP-1) concentrations in response to a standard breakfast. (A) Plasma concentrations expressed as change from the fasted sample at time point $0(\Delta)$ before weight loss $(-\square-)$, after weight loss $(-\boldsymbol{\Delta}-)$ and after weight maintenance $(-\bullet-)$. Data are presented as means, with their standard errors represented by vertical bars. *Mean value was significantly different from that after weight maintenance $(P<0.05)$. + Mean value was significantly different from that after weight loss $(P<0.05)$. (B) Area under the curve (AUC) calculated as incremental $A U C \times 2 h$ before weight loss (T1), after weight loss (T2) and after weight maintenance (T3). Data are presented as means, with their standard errors represented by vertical bars. *Mean values were significantly different $(P<0.05)$. For details of subjects and procedures, see p. 161. 
Plasma insulin concentrations were significantly increased compared with fasting concentrations after breakfast at 30 , 60, 90 and $120 \mathrm{~min}$ at $\mathrm{T} 1\left(F_{1,31} 8.2 ; P<0.05, F_{1,31} 11.5\right.$; $\left.P<0.05, F_{1,31} 10 \cdot 1 ; P<0.05, F_{1,31} 8 \cdot 3 ; P<0.05\right)$, T2 $\left(F_{1,31}\right.$ 8.0; $P<0.05, F_{1,31} 11 \cdot 1 ; P<0.05, F_{1,31} 9.4 ; P<0.05, F_{1,31}$ $8.8 ; \quad P<0.05)$ and T3 $\left(F_{1,31} \quad 8.2 ; \quad P<0.05, \quad F_{1,31} \quad 11.5\right.$; $\left.P<0.05, F_{1,31} 10 \cdot 1 ; P<0.05, F_{1,31} 8 \cdot 3 ; P<0 \cdot 05\right)$. No differences were observed between T1, T2 and T3 in insulin concentrations (Fig. 3). Insulin resistance calculated using homeostasis model assessment (Kanauchi et al. 2003) showed no differences in insulin resistance after weight loss (2.53 (SEM 0.26)) compared with before weight loss (2.54 (SEM 0.25))

Plasma glucose concentrations were significantly increased at 60 min after breakfast compared with fasting concentrations at T1 (5.52 (SEM 0.12) v. $6.44(\operatorname{SEM} 0.26))\left(F_{1,31} 9.3 ; P<0.05\right)$, T2 (5.07 (SEM 0.10) v. 6.08 (SEM 0.23)) $\left(F_{1.31} 9.9 ; P<0.05\right)$ and T3 (5.36 (SEM 0.12) v. 6.61 (SEM 0.32)) $\left(F_{1,31} 10 \cdot 7\right.$; $P<0 \cdot 05)$. No differences were observed between T1, T2 and T3 (Fig. 4).

Fasting plasma NEFA concentrations were 417.4 (SEM 27.5), 505.7 (SEM 38.7) and 416.8 (SEM 26.9) $\mu \mathrm{mol} / \mathrm{l}$ at T1, $\mathrm{T} 2$ and $\mathrm{T} 3$ respectively.

These concentrations decreased over time at T1, T2 and T3. The decreases compared with fasting concentrations $(\Delta)$ were significant at 60, 90 and $120 \mathrm{~min}$ before weight loss $\left(F_{1,31} 9 \cdot 3\right.$; $\left.P<0.05, F_{1,31} 9.9 ; P<0.05, F_{1,31} 11.8 ; P<0.05\right)$, after weight loss $\left(F_{1,31} 9 \cdot 1 ; P<0.05, F_{1,31} 10 \cdot 0 ; P<0.05, F_{1,31} 12 \cdot 0\right.$; $P<0.05)$ and after weight maintenance $\left(F_{1,31} 9 \cdot 1 ; P<0.05\right.$, $\left.F_{1,31} 9.5 ; P<0.05, F_{1,31} 10.7 ; P<0.05\right)$. The area under the curve for NEFA concentrations $(\mu \mathrm{mol} / \mathrm{l} \times 2 \mathrm{~h})$ was significantly higher at T2 (598.2 (SEM 47.9)) compared with T1 (435.7 (SEM 23.2)) $\left(F_{2,30} 19.4 ; P<0.01\right)$ and compared with T3 (471.8 (SEM 34.1)) $\left(F_{2,30} 22 \cdot 6 ; P<0 \cdot 01\right)$ (Fig. 5).

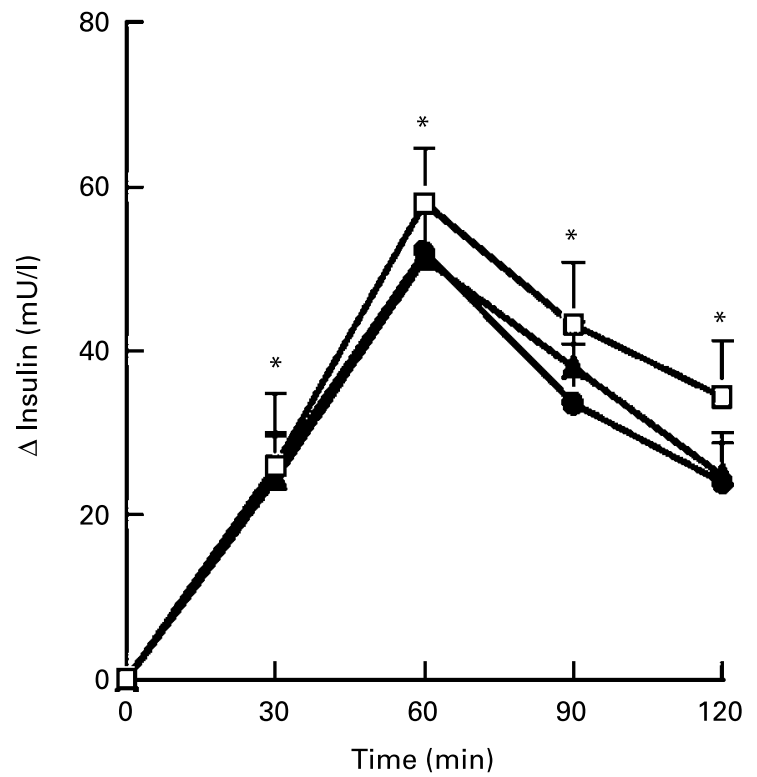

Fig. 3. Plasma concentrations of insulin after ingestion of a standard breakfast before weight loss (- $\square-)$, after weight loss $(-\mathbf{\Lambda}-)$ and after weight maintenance (-) . Data are presented as means, with their standard errors represented by vertical bars. For details of subjects and procedures, see p. 161.

\section{Appetite ratings}

Hunger ratings (Fig. 6) did not differ significantly between T1, $\mathrm{T} 2$ and $\mathrm{T} 3$ at baseline, at 30,60 and $90 \mathrm{~min}$. Hunger scores decreased after breakfast at T1, T2 and T3. Hunger was significantly decreased at $120 \mathrm{~min}$ after weight loss compared with before weight loss $\left(F_{2,30} 4 \cdot 64 ; P<0 \cdot 05\right)$.

Satiety ratings increased after breakfast compared with fasted ratings at $\mathrm{T} 1, \mathrm{~T} 2$ and $\mathrm{T} 3$ and stayed elevated compared with the fasted ratings throughout the $2 \mathrm{~h}$ of measurement. No differences between T1, T2 and T3 were observed over time (Fig. 7).

Appetite ratings were not related to plasma GLP-1 concentrations.

\section{Discussion}

The present study shows decreased plasma GLP-1 concentrations after modest weight loss in overweight and obese subjects. After a weight-maintenance period of 3 months GLP-1 concentrations rebound to a level similar to before weight loss. After weight loss, not only fasting GLP-1 concentrations seemed to be decreased compared with before weight loss, but it appears that nutrient-stimulated GLP-1 release was disturbed after weight loss as well.

This observation might be an effect of the semi-solid VLED that the subjects followed during weight loss. A study comparing a liquid and a solid test meal in healthy, normal-weight subjects revealed a difference in gastric-emptying time, but not in small-bowel transit time for a liquid and a solid test meal (Bennink et al. 1999). Altered gastric emptying rates, and increased proximal absorption rates of a liquid test meal in obese subjects (Wisen \& Johansson, 1992), possibly resulting in less food reaching the distal intestine, are suggested as a possible explanation for decreased GLP-1 release (Vilsboll et al. 2003). Thus, the absorption rate of the semi-solid

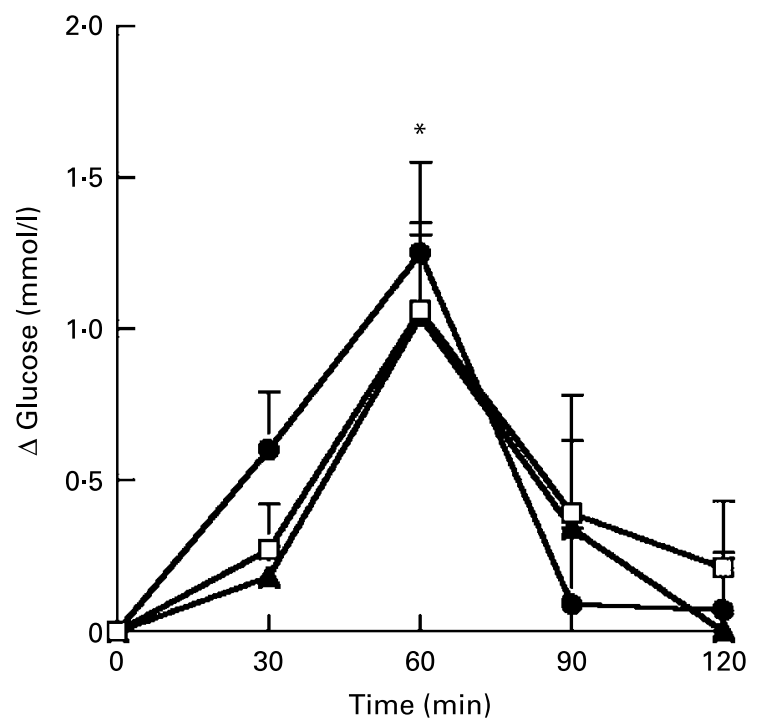

Fig. 4. Plasma concentrations of glucose after ingestion of a standard breakfast before weight loss $(-\square-)$, after weight loss $(-\boldsymbol{\Lambda}-)$ and after weight maintenance (-) . Data are presented as means, with their standard errors represented by vertical bars. For details of subjects and procedures, see p. 161. 

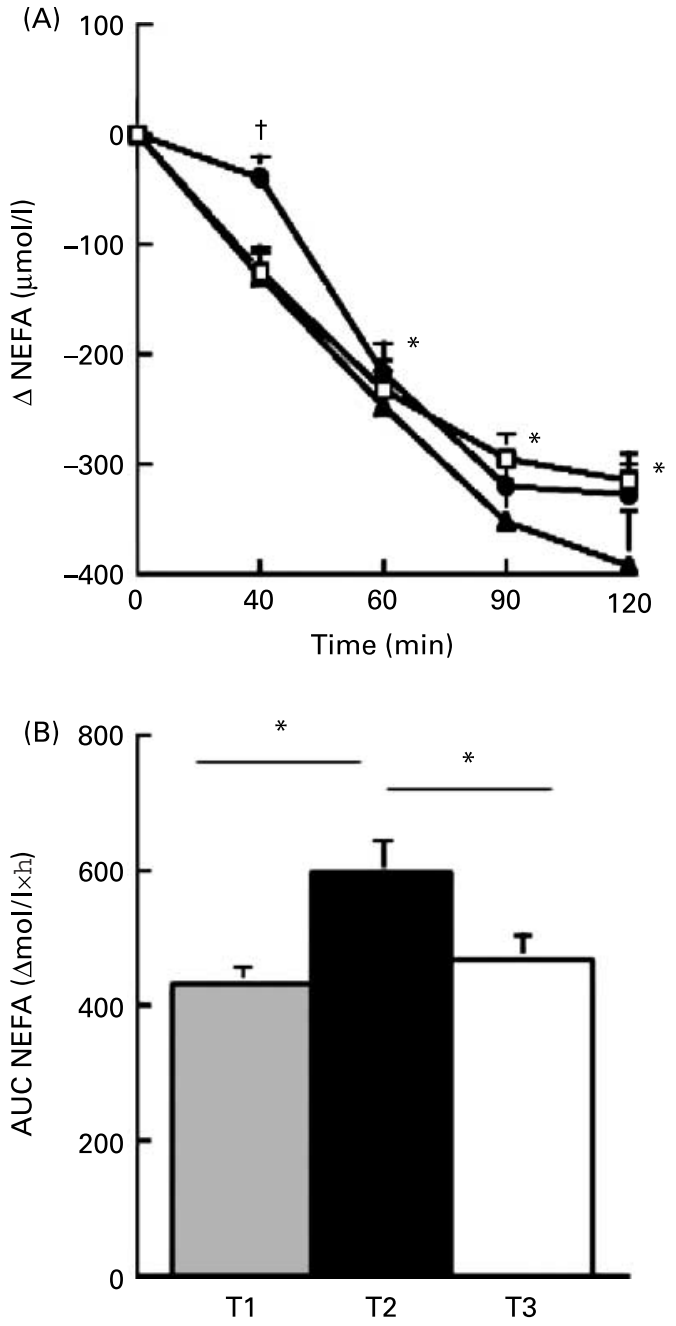

Fig. 5. Plasma concentrations of NEFA after ingestion of a standard breakfast. (A) Plasma concentrations expressed as change from the fasting sample at time point $0(\Delta)$ before weight loss $(-\square-)$, after weight loss $(-\mathbf{\Delta}-)$ and after weight maintenance $(-\bullet-)$. Data are presented as means, with their standard errors represented by vertical bars. * Significantly different concentrations compared with fasting concentrations at 0 min after ingestion of a standard breakfast before weight loss, after weight loss and after weight maintenance $(P<0.05)$. †Significant difference compared with baseline plasma concentrations after weight maintenance compared with before weight loss and after weight loss $(P<0.05)$. (B) Area under the curve (AUC) calculated as incremental AUC $\times 2 \mathrm{~h}$ before weight loss (T1), after weight loss (T2) and after weight maintenance (T3). Data are presented as means, with their standard errors represented by vertical bars. ${ }^{*}$ Mean values were significantly different $(P<0.05)$. For details of subjects and procedures, see p. 161.

VLED in the presence of a negative energy balance might have led to the decrease of GLP-1 secretion after weight loss in the overweight and obese subjects. It needs to be taken into consideration that the reported results in the present study also might be due to a decreased stimulation of the Lcells. Peptide YY is a peptide co-localised with GLP-1 in the L-cells of the gut. GLP-1 infusion studies showed significantly decreased peptide YY concentrations as a response to GLP-1 infusion, giving evidence that L-cell secretion is regulated in part by GLP-1 itself through negative feedback regulation (Näslund et al. 1999b; Hansen et al. 2004). Since in those studies GLP-1 concentrations were elevated to

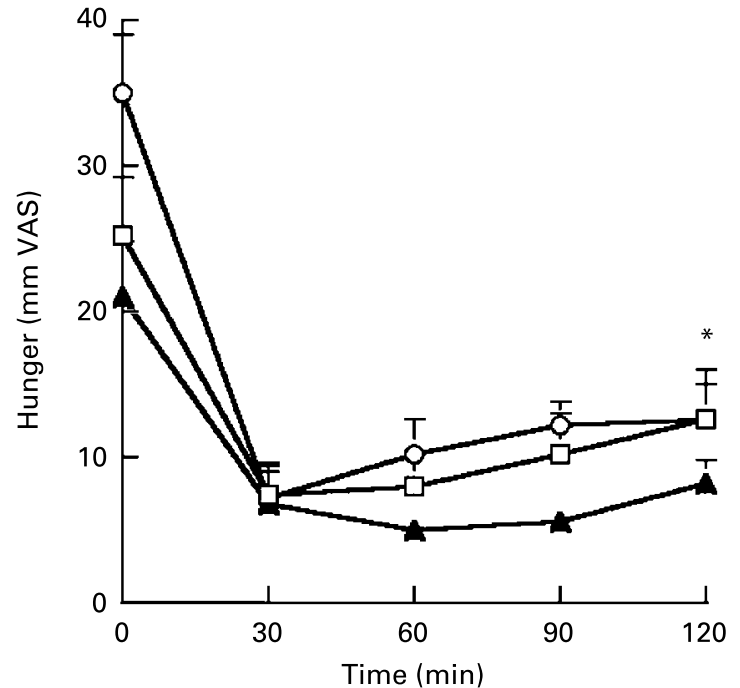

Fig. 6. Hunger ratings (mm visual analogue score; VAS) before weight loss $(-\square-)$, after weight loss $(-\boldsymbol{\Lambda}-)$ and after weight maintenance $(-\bigcirc-)$. Data are presented as means, with their standard errors represented by vertical bars. *Mean value was significantly different from that after weight loss $(P<0.05)$. For details of subjects and procedures, see p. 161.

supraphysiological levels (Näslund et al. 1999b), the question remains in how far the results apply to rather a low range of physiological GLP-1 concentrations in the present study (Flint et al. 2001).

During the weight-maintenance period subjects appeared to have stable body weight.

Surprisingly, after the 3 months weight-maintenance period, GLP-1 concentrations were rebounded back to a level comparable with before weight loss. The decrease of GLP-1 secretion after weight loss might be due to a negative energy balance and may suggest that GLP-1 might play a role as a neuroendocrine factor signalling energy deficiency.

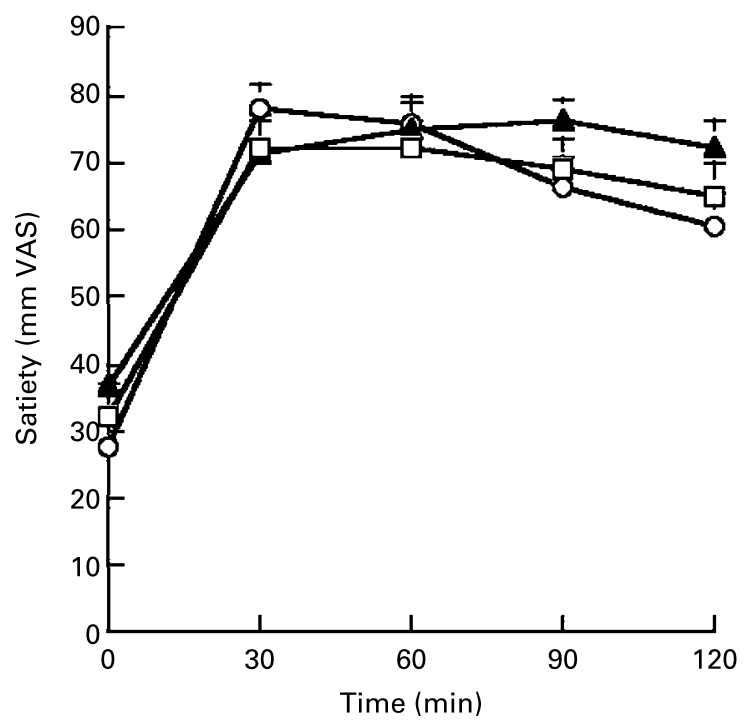

Fig. 7. Satiety ratings ( $\mathrm{mm}$ visual analogue score; VAS) before weight loss $(-\square-)$, after weight loss $(-\boldsymbol{\Lambda}-)$ and after weight maintenance $(-\bigcirc-)$. Data are presented as means, with their standard errors represented by vertical bars. For details of subjects and procedures, see p. 161. 
The overall pattern of GLP-1 release during T1, T2 and T3 is following the biphasic pattern, that has been described before (Herrmann et al. 1995). GLP-1 release has been reported as attenuated in obese subjects compared with normal-weight subjects (Ranganath et al. 1996). This observation has been explained by increased DPP-IV activity, for example (Lugari et al. 2004). However, based upon the literature on DPP-IV activity in obese subjects, where abnormally increased DPP-IV activity could be observed in the obese even after substantial weight loss, it seems unlikely that altered DPP-IV activity is an explanation for different GLP1 release at T1, T3 and T2 in the present study.

Due to the negative energy balance during weight loss, NEFA concentrations were increased after weight loss compared with before weight loss. An increase in plasma NEFA has been found to inhibit carbohydrate-mediated GLP-1 secretion (Ranganath et al. 1996, 1999), so that increased plasma NEFA after weight loss in the present study, might in part contribute to decreased GLP-1 secretion after the standard breakfast.

As expected, the RQ measured after the VLED was reduced (Lejeune et al. 2003a), indicating increased fat oxidation. RQ was increased again after 3 months of weight maintenance. REE as a function of FFM did not change over time. Since the main determinant of REE is FFM (Ravussin \& Bogardus, 1989) and FFM did not change over time either, this result is not surprising. Subjects mainly lost fat mass, as can be seen in the significant reduction in percentage fat mass. Weight lost during the VLED was comparable with weight loss over this period of time in other studies (Lejeune et al. 2003a; Kovacs et al. 2004) and consisted mainly of fat mass, which seems to be favourable for the prevention of weight regain. This is in line with studies showing that weight regain was slower, when body weight regained consisted of a greater FFM (Pasman et al. 1999; Westerterp-Plantenga et al. 2004). Weight loss was $6 \mathrm{~kg}$ on average. This means that subjects consumed an average energy of $4.2 \mathrm{MJ} / \mathrm{d}$, providing evidence for a very negative energy balance, but also showing that subjects did not stick to the VLED completely. The difference of $1.6 \mathrm{MJ} / \mathrm{d}$ cannot be explained by the additional intake of $200 \mathrm{~g}$ fruit or vegetables.

During a weight-maintenance period subjects usually regain weight (Lejeune et al. 2003a,b). Subjects in the present study did not regain weight significantly during weight maintenance. Part of an explanation for this might be either individual motivation or the weather (Plasqui et al. 2003). The summer of 2003 was an exceptionally warm one; June 2003 was the warmest June since 1901 with $17.8^{\circ} \mathrm{C}$. Subjects had their weight-maintenance period in the months between April and July 2003.

Another important factor in successful weight maintenance is the restraint status of the subjects, which was increased significantly after weight loss and stayed increased after weight maintenance. It has been shown that, on the individual level, differences in successful weight maintenance after an energy-restriction period are related to increases in cognitively restrained eating behaviour during the energy-restriction phase (Clark et al. 1994; Pekkarinen et al. 1996; Westerterp-Plantenga et al. 1998; Lejeune et al. 2003b). This was supported by a decrease in disinhibition and hunger during weight loss and weight maintenance.
Differences in hunger and satiety ratings were observed at only one time point after weight loss compared with before weight loss, an observation that is similar to reports from other studies (Lejeune et al. 2003a). Ratings were not different after the weight-maintenance period either. Again, this might be due to the weather or could be explained by lower energy requirements due to weight loss.

Evaluating the hunger and satiety ratings as well as the blood parameters it is important to mention that the size of the test meal was the same at every occasion, although energy requirements changed. This is a procedure similar to other dietary-induced weight-loss studies (Verdich et al. 2001b).

Different from other studies, no relationship between satiety ratings and GLP-1 concentrations were observed in the present study. GLP-1 release in the present study was exclusively meal induced. Many studies so far have been working with GLP-1 infusions, leading to an increase in GLP-1 concentrations up to about $50 \mathrm{pmol} / \mathrm{l}$ (Flint et al. 1998). A meta-analysis has shown that the effect of GLP-1 on the reduction of energy intake is dose dependent (Verdich et al. 2001b). The present study only shows a meal-related increase in GLP-1 concentrations of about $2.5 \mathrm{pmol} / \mathrm{l}$. This elevation might not be strong enough to have a significant impact on satiety sensation. Another study that investigated meal-induced GLP-1 release did not find a clear effect of GLP-1 on satiety either (Verdich et al. 2001b), although investigating a meal of $2.5 \mathrm{MJ}, 0.5 \mathrm{MJ}$ more than what was used in the present study and a meal-related increase in GLP-1 of about $6 \mathrm{pmol} / \mathrm{l}$. Decrease in hunger ratings was not related to the increase in GLP-1 concentrations after weight maintenance. Both rather seem to reflect a new state of energy balance achieved.

One important shortcoming of the present study that needs to be mentioned is the comparison with a control group; that and more research is needed to compare the outcome and results concerning the effect of weight loss by means of a semi-solid diet on GLP-1 release.

In conclusion, nutrient-stimulated GLP-1 release was decreased after weight loss, but rebounded to a level similar to before weight loss after a weight-maintenance period. The rebound in nutrient-stimulated GLP-1 release makes it likely that the absence of nutrient-stimulated GLP-1 release after weight loss is transient and might be due to a negative energy balance.

\section{Acknowledgements}

The present study was supported by Novartis, Consumer Health, Nyon. The authors gratefully acknowledge Kathleen Melanson for expert assistance.

\section{References}

Bennink R, Peeters M, van den Maegdenbergh V, Geypens B, Rutgeerts P, De Roo M \& Mortelmans L (1999) Evaluation of small-bowel transit for solid and liquid test meals in healthy men and women. Eur J Nucl Med 26, 1560-1566.

Blundell JE, Lawton CL \& Hill AJ (1993) Mechanisms of appetite control and their abnormalities in obese patients. Horm Res $\mathbf{3 9}$, $72-76$. 
Blundell JE \& Näslund E (1999) Glucagon-like peptide-1, satiety and appetite control. Br J Nutr 81, 259-260.

Cigaina V \& Hirschberg AL (2003) Gastric pacing for morbid obesity: plasma levels of gastrointestinal peptides and leptin. Obes Res 11, 1456-1462.

Clark MM, Marcus BH, Pera V \& Niaura RS (1994) Changes in eating inventory scores following obesity treatment. Int $J$ Eat Disord 15, 401-405.

Flint A, Raben A, Astrup A \& Holst JJ (1998) Glucagon-like peptide 1 promotes satiety and suppresses energy intake in humans. $J$ Clin Invest 101, 515-520.

Flint A, Raben A, Ersboll AK, Holst JJ \& Astrup A (2001) The effect of physiological levels of glucagon-like peptide 1 on appetite, gastric emptying, energy and substrate metabolism in obesity. Int $J$ Obes Relat Metab Disord 25, 781-792.

Fukase N, Igarashi M, Takahashi H, Manaka H, Yamatani K, Daimon M, Tominaga M \& Sasaki H (1993) Hypersecretion of truncated glucagon-like peptide-1 and gastric inhibitory polypeptide in obese patients. Diabet Med 10, 44-49.

Hansen L, Hartmann B, Mineo H \& Holst JJ (2004) Glucagon-like peptide-1 secretion is influenced by perfusate glucose concentration and by a feedback mechanism involving somatostatin in isolated perfused porcine ileum. Regul Pept 118, 11-18.

Herrmann C, Göke R, Richter G, Fehmann HC, Arnold R \& Göke B (1995) Glucagon-like peptide-1 and glucose-dependent insulinreleasing polypeptide plasma levels in response to nutrients. Digestion 56, 117-126.

Holst JJ (1994) Glucagonlike peptide 1: a newly discovered gastrointestinal hormone. Gastroenterology 107, 1848-1855.

Kanauchi M, Yamano S, Kanauchi K \& Saito Y (2003) Homeostasis model assessment of insulin resistance, quantitative insulin sensitivity check index and oral glucose insulin sensitivity index in nonobese, nondiabetic subjects with high-normal blood pressure. $J$ Clin Endocrinol Metab 88, 3444-3446.

Kovacs EM, Lejeune MP, Nijs I \& Westerterp-Plantenga MS (2004) Effects of green tea on weight maintenance after body-weight loss. Br J Nutr 91, 431-437.

Lejeune MP, Kovacs EM \& Westerterp-Plantenga MS (2003a) Effect of capsaicin on substrate oxidation and weight maintenance after modest body-weight loss in human subjects. Br J Nutr 90 651-659.

Lejeune MP, van Aggel-Leijssen DP, van Baak MA \& Westerterp-Plantenga MS (2003b) Effects of dietary restraint vs exercise during weight maintenance in obese men. Eur J Clin Nutr 57, 1338-1344.

Lugari R, Dei Cas A, Ugolotti D et al. (2004) Glucagon-like peptide 1 (GLP-1) secretion and plasma dipeptidyl peptidase IV (DPP-IV) activity in morbidly obese patients undergoing biliopancreatic diversion. Horm Metab Res 36, 111-115.

Murphy KG \& Bloom SR (2004) Gut hormones in the control of appetite. Exp Physiol 89, 507-516.

Näslund E, Barkeling B, King N, Gutniak M, Blundell JE, Holst JJ, Rössner S \& Hellström PM (1999a) Energy intake and appetite are suppressed by glucagon-like peptide-1 (GLP-1) in obese men. Int J Obes Relat Metab Disord 23, 304-311.

Näslund E, Bogefors J, Skogar S, Gryback P, Jacobsson H, Holst JJ \& Hellström PM (1999b) GLP-1 slows solid gastric emptying and inhibits insulin, glucagon, and PYY release in humans. Am J Physiol 277, R910-R916.

Nathan DM, Schreiber E, Fogel H, Mojsov S \& Habener JF (1992) Insulinotropic action of glucagonlike peptide-I-(7-37) in diabetic and nondiabetic subjects. Diabetes Care 15, 270-276.

Pasman WJ, Saris WH, Muls E, Vansant G \& Westerterp-Plantenga MS (1999) Effect of exercise training on long-term weight maintenance in weight-reduced men. Metabolism 48, 15-21.

Pekkarinen T, Takala I \& Mustajoki P (1996) Two year maintenance of weight loss after a VLCD and behavioural therapy for obesity: correlation to the scores of questionnaires measuring eating behaviour. Int J Obes Relat Metab Disord 20, 332-337.

Peronnet F \& Massicotte D (1991) Table of nonprotein respiratory quotient: an update. Can J Sport Sci 16, 23-29.

Plasqui G, Kester AD \& Westerterp KR (2003) Seasonal variation in sleeping metabolic rate, thyroid activity, and leptin. Am J Physiol 285, E338-E343.

Ranganath L, Norris F, Morgan L, Wright J \& Marks V (1999) Inhibition of carbohydrate-mediated glucagon-like peptide-1 (7-36) amide secretion by circulating non-esterified fatty acids. Clin Sci (Lond) 96, 335-342.

Ranganath LR, Beety JM, Morgan LM, Wright JW, Howland R \& Marks V (1996) Attenuated GLP-1 secretion in obesity: cause or consequence?" Gut 38, 916-919.

Ravussin E \& Bogardus C (1989) Relationship of genetics, age, and physical fitness to daily energy expenditure and fuel utilization. $\mathrm{Am}$ $J$ Clin Nutr 49, 968-975.

Schoeller DA, van Santen E, Peterson DW, Dietz W, Jaspan J \& Klein PD (1980) Total body water measurement in humans with $18 \mathrm{O}$ and 2H labeled water. Am J Clin Nutr 33, 2686-2693.

Schoffelen PF, Westerterp KR, Saris WH \& Ten Hoor F (1997) A dual-respiration chamber system with automated calibration. J Appl Physiol 83, 2064-2072.

Siri WE (1956) The gross composition of the body. Adv Biol Med Physiol 4, 239-280.

Stunkard AJ \& Messick S (1985) The three-factor eating questionnaire to measure dietary restraint, disinhibition and hunger. $J P s y$ chosom Res 29, 71-83.

van Gaal LF, Wauters MA \& De Leeuw IH (1997) The beneficial effects of modest weight loss on cardiovascular risk factors. Int J Obes Relat Metab Disord 21, Suppl. 1, S5-S9.

van Marken Lichtenbelt WD, Westerterp KR \& Wouters L (1994) Deuterium dilution as a method for determining total body water: effect of test protocol and sampling time. Br J Nutr 72, 491-497.

Verdich C, Flint A, Gutzwiller J-P, Näslund E, Beglinger C, Hellstroem PM, Long SJ, Morgan LM, Holst JJ \& Astrup A (2001a) A meta-analysis of the effect of glucagon-like peptide-1 (7-36) amide on ad libitum energy intake in humans. J Clin Endocrinol Metab 86, 4382-4389.

Verdich C, Toubro S, Buemann B, Lysgard Madsen J, Juul Holst J \& Astrup A (2001b) The role of postprandial releases of insulin and incretin hormones in meal-induced satiety - effect of obesity and weight reduction. Int $J$ Obes Relat Metab Disord 25, $1206-1214$.

Vilsboll T, Krarup T, Sonne J, Madsbad S, Volund A, Juul AG \& Holst JJ (2003) Incretin secretion in relation to meal size and body weight in healthy subjects and people with type 1 and type 2 diabetes mellitus. $J$ Clin Endocrinol Metab 88, 2706-2713.

Weir JB (1949) New methods for calculating metabolic rate with special reference to protein metabolism. Nutrition 6, 213-221.

Westerterp-Plantenga MS, Kempen KP \& Saris WH (1998) Determinants of weight maintenance in women after diet-induced weight reduction. Int J Obes Relat Metab Disord 22, 1-6.

Westerterp-Plantenga MS, Lejeune MP, Nijs I, van Ooijen M \& Kovacs EM (2004) High protein intake sustains weight maintenance after body weight loss in humans. Int J Obes Relat Metab Disord 28, 57-64.

Westerterp-Plantenga MS, Rolland V, Wilson SA \& Westerterp KR (1999) Satiety related to $24 \mathrm{~h}$ diet-induced thermogenesis during high protein/carbohydrate vs high fat diets measured in a respiration chamber. Eur J Clin Nutr 53, 495-502.

Wisen O \& Johansson C (1992) Gastrointestinal function in obesity: motility, secretion, and absorption following a liquid test meal. Metabolism 41, 390-395.

World Health Organization (1998) Obesity: Preventing and Managing the Global Epidemic. Geneva: WHO. 